\title{
First documented record of a living solemyid bivalve in a pockmark of the Nile Deep-sea Fan (eastern Mediterranean Sea)
}

\author{
CLARA F. RODRIGUES ${ }^{1,2}$, SÉBASTIEN DUPERRON ${ }^{1}$ AND SYLVIE M. GAUDRON ${ }^{1}$ \\ ${ }^{1}$ Université Pierre-et-Marie-Curie, UMR 7138 (UPMC CNRS IRD MNHN), Systématique Adaptation, Evolution, Paris, 75052, \\ France, ${ }^{2}$ CESAM \& Department of Biology, Universidade de Aveiro, Aveiro, 3810-193, Portugal
}

\begin{abstract}
A living specimen of a solemyid bivalve was collected at bathyal depths near a pockmark in the Nile Deep-sea Fan (eastern Mediterranean) and is here presented. Both taxonomic and molecular results suggest a Solemya species but due to the small size of the animal and the lack of molecular data for other solemyid species the species cannot be determined. This is the first record of a living solemyid from deep-sea cold seeps in the Mediterranean Basin.
\end{abstract}

Keywords: Solemyidae, cold seeps, eastern Mediterranean

Submitted 20 October 2010; accepted 22 December 2010

\section{INTRDDUCTIDN}

With a fossil record extending back into the Lower Palaeozoic, Solemyidae are the oldest chemosymbiotic bivalves (Taviani, 2010). Solemyids live in ' $U$ '- or ' $Y$ '-shaped burrows; shells display an elongate, near cylindrical shape and are covered with glossy, thick, brown periostracum extended as a broad, pleated, flexible fringe (Reid, 1998; Taylor \& Glover, 2010).

Solemyids are geographically widespread at depths ranging from the intertidal to $5350 \mathrm{~m}$ (Fujiwara, 2003), and often associate with organically enriched habitats (reviewed in Taylor \& Glover, 2010). The family Solemyidae is well documented at cold seeps in the Pacific, where mainly empty shells have been observed in low numbers (Sibuet \& Olu, 1998; Sahling et al., 2002; Neulinger et al., 2006; Kamenev, 2009). Only recently they have been found in cold seeps from the North Atlantic, (Oliver et al., submitted). To date, more than 30 species are known but continuous progress in deep sea investigation could rapidly increase this number (Neulinger et al., 2006; Kamenev, 2009).

In the Mediterranean Sea a single species (Solemya togata) has been reported from shallow coastal waters' settings such as seagrass beds. On the other hand, large size solemyids ('Acharax' doderleini) are known from Neogene deposits of this basin interpreted as deep-sea reducing habitats (Taviani et al., 2008; Taviani, 2010).

This paper reports on the first solemyid recorded from bathyal depths in the Mediterranean Sea, based on a single living specimen found at $1697 \mathrm{~m}$ depth in the central province of the Nile Deep-sea Fan (eastern Mediterranean), where fluid seepage was reported in several locations (Dupré et al., 2007; Bayon et al., 2009).

Corresponding author:

C.F. Rodrigues

Email: clfrodrigues@gmail.com

\section{MATERIALS AND METHDDS}

A single specimen of a solemyid bivalve was cored in soft sediment next to an active pockmark area of the Nile Deep-sea Fan (eastern Mediterranean Sea) (Station TVMUC1059; $32^{\circ} 32.05^{\prime} \mathrm{N} 30^{\circ} 21.13^{\prime} \mathrm{E}, 1697 \mathrm{~m}$ depth) using a TVMUC onboard the RV 'Maria S Merian' (Germany) (chief scientist: F. Wenzhöfer) during the MSM13/4 (HOMER) cruise (Figure 1). All metadata are stored in the PANGAEA database (http://www.pangaea.de).

After collection the only available specimen (shell partly broken during sampling) was fixed in ethanol. Due to the single broken specimen available and its small size $(7.5 \mathrm{~mm}$ shell length), detailed morphological identification was not possible and molecular tools were employed to help clarify its taxonomic position. DNA was extracted from gill tissue using the DNeasy Blood and Tissue Kit (QIAGEN, CA). Multiple marker genes (18S rRNA, 28S rRNA and cytochrome $c$ oxidase subunit (COI)) were PCR amplified using primers and conditions described previously (Folmer et al., 1994; Taylor et al., 2007) and sequenced (GATC Biotech, Germany). The presence of bacterial symbionts was also tested using PCR amplification of bacterial $16 \mathrm{~S}$ rRNA genes (Duperron et al., 2007).

Sequences were compared with the GenBank database using BLAST to identify sequences with highest similarities. Gene sequences were deposited in the EMBL database (http://www.ebi.ac.uk/embl) under Accession numbers FR715296 (18S), FR715297 (28S), and FR715326 (COI).

\section{RESULTS AND DISCUSSIDN}

The solemyid shell presented the features reported for the genus Solemya. For instance, the shell was thin, flexible, poorly mineralized, elongate-oval, inflated to compressed, and its surface displayed widely spaced weak radial ribs. The 


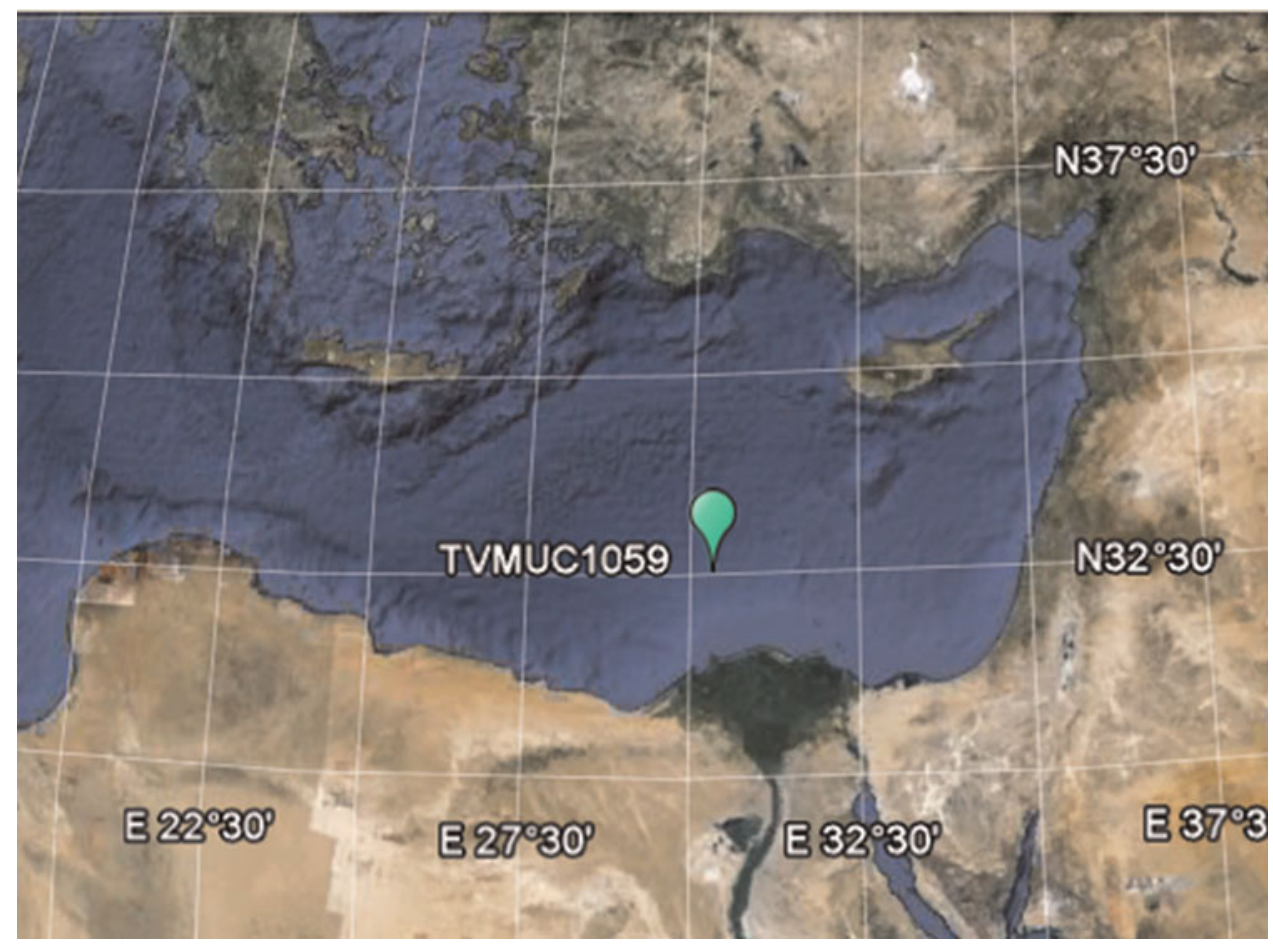

Fig. 1. Map of the study area $\left({ }^{\circ}\right.$ Google Earth).

ligament was opisthodetic, internal, and attached to chondrophore (Figure 2). A reduced digestive tract was also visible.

The $18 \mathrm{~S}$ rRNA-encoding gene displayed $93 \%$ similarity with a sequence from Solemya velum $18 \mathrm{~S}$ ribosomal RNA gene (AF120524) (Giribet et al., 2000); the $28 \mathrm{~S}$ rRNA-encoding gene displayed $99 \%$ similarity with a sequence from S. velum $28 \mathrm{~S}$ ribosomal RNA gene (AY45421) (Passmaneck et al., 2004); the COI sequence yielded $83 \%$ sequence similarity with S. velum cytochrome $c$ oxidase subunit I (U56852) (Hoeh et al., 1998). Molecular results thus relate the present specimen with $S$. velum, a species from the north-west Atlantic that lives in sulphide-rich coastal sediments. Unfortunately, few $18 \mathrm{~S}$ and $28 \mathrm{~S}$, and no COI sequences are available for the two genera of the family (Solemya and Acharax), so molecular data cannot yet be invoked as support for the generic affiliation with Solemya.

At this point, and in the absence of appropriate data on other species for comparison, it also seems impossible to determine the species or to postulate for a new species. Nevertheless several hypotheses may be suggested. First, the specimen here studied could be related to the shallow species Solemya togata (no available sequence) and could be the result of an evolutionary process from shallow to deep waters as already documented in other bivalve species (e.g. mytilids; Jones et al., 2006). An alternative hypothesis would be that the specimen is a living relative of the recorded fossil 'Acharax' doderleini.

The majority of Solemya species have been found in shallow depths, but Kamenev (2009) reported the occurrence of Solemya pervernicosa in Sagami Bay cold seeps at 1510 m; thus the occurrence of a Solemya species in the eastern Mediterranean at $1697 \mathrm{~m}$ would be not surprising.

Large size solemyids ascribed to the genus Acharax are known to have inhabited the Mediterranean in the past (Taviani, 2010). Solemyids were widely distributed in

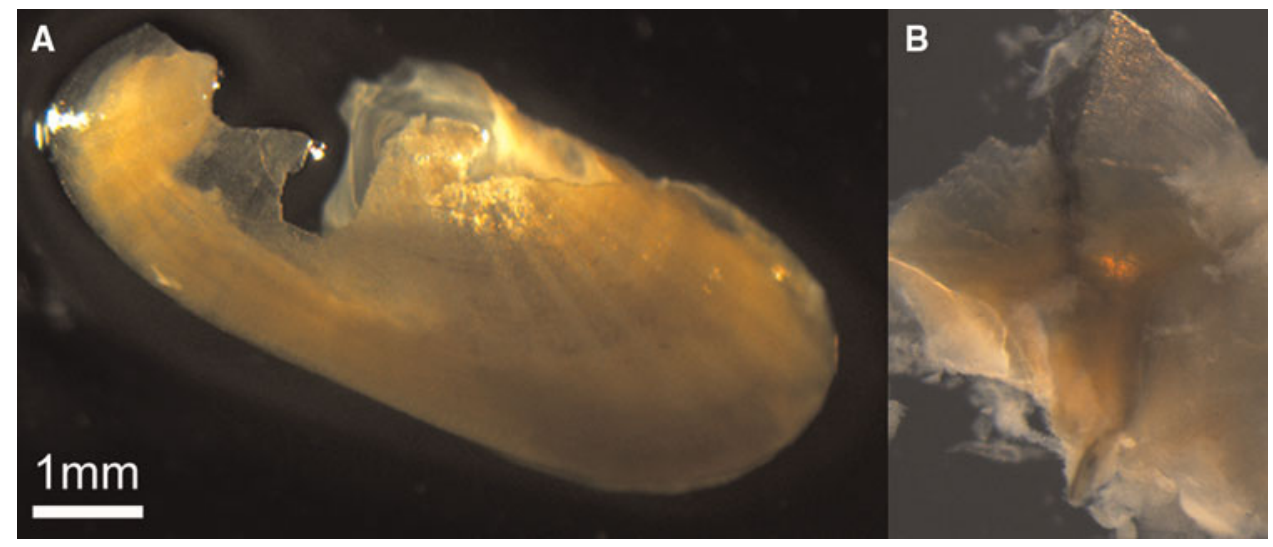

Fig. 2. Solemyidae found in the central province of the Nile Deep-sea Fan: (A) broken shell; (B) ligament detail. 
Miocene deep-sea reducing habitats and, after the Messinian salinity crisis (MSC), re-colonized suitable reducing environments up to the Middle Pliocene (Taviani et al., 2008). The putative absence of deep-sea solemyids in the present Mediterranean was puzzling and it was tentatively suggested to be possibly related to temperature (Taviani et al., 2008), although it was anticipated that this absence was only apparent (Taviani, 2010)

Until further molecular data becomes available on other species, these hypotheses cannot be tested.

Despite repeated attempts, no bacterial $16 \mathrm{~S}$ rRNA gene sequence was amplified. In all previous studies Solemyidae are presented as 'symbiont dependent', with some species having small, reduced, or even absent alimentary tracts (reviewed in Taylor \& Glover, 2010). A weak suspension feeding capability is retained in S. velum (Krueger et al., 1992). This capability could occur in other species and explain the absence of symbionts, but the most likely hypothesis remains that the protocols employed here actually failed to amplify symbiont DNA.

With the discovery of the first living solemyid at a depth of $1697 \mathrm{~m}$ in a cold seep in the eastern Mediterranean, this work extends the known distribution of this bivalve family. More research is needed to explore the deep richness of the Mediterranean Sea where a number of potentially suitable habitats for solemyids are present (Taviani, 2010). Nevertheless we expect to sample more specimens in the future to confidently assess the taxonomic position of Mediterranean deep-water solemyids and to unravel their evolutionary and biogeographical connections.

\section{ACKNDWLEDGEMENTS}

We thank Professor Antje Boetius and Dr Frank Wenzhöfer for inviting us on the MSM13/4 (HOMER) cruise. The captain and crew of the RV 'Maria S. Merian' and pilots of the ROV 'Quest' are acknowledged for their skilful work. We are indebted to Dr Ann Vanreusel for the precious collaboration offered during the mission. Finally, we would like to thank the three anonymous referees for their comments that helped improve the manuscript. This research was supported by the European Commission Seventh Framework Programme (FP7/2007-2013) under the HERMIONE project, Contract number 226354; MPG-CNRS-GDRE 'Diversity, establishment and function of organisms associated with marine wood falls-DIWOOD'; ANR DEEP-OASES (ANRO6BDVo05) and CHEMECO ESF EURODEEP. C.F.R. was also supported by a post-doctoral fellowship (SFRH/ BPD/64154/2009) from the Fundação para a Ciência e a Tecnologia (Portugal).

\section{REFERENCES}

Bayon G., Loncke L., Dupré S., Caprais J.C., Ducassou E., Duperron S., Etoubleau J., Foucher J.P., Fouquet Y., Gontharet S., Henderson G.M., Huguen C., Klauche I., Mascle J., Migeon S., Olu-le Roy K., Ondréas H., Pierre C., Sibuet M., Stadnitskaia A. and Woodside J. (2009) Multi-disciplinary investigation of fluid seepage on an unstable margin; the case of the Central Nile Deep-sea Fan. Marine Geology 261, 92-104.
Duperron S., Fiala-Medioni A., Caprais J.C., Olu K. and Sibuet M. (2007) Evidence for chemoautotrophic symbiosis in a Mediterranean cold seep clam (Bivalvia: Lucinidae): comparative sequence analysis of bacterial $16 \mathrm{~S}$ rRNA, APS reductase and RubisCO genes. FEMS Microbiology Ecology 59, 64-70.

Dupré S., Woodside J., Foucher J.P., Lange G. de, Mascle J., Boetius A., Mastalerz V., Stadnitskaia A., Ondréas H., Huguen C., Harmégnies F., Gontharet S., Loncke L., Deville E., Niemann H., Omoregie E.O., Olu-Le Roy K., Fiala-Medioni A., Dahlmann A., Caprais J.C., Prinzhofer A., Sibuet M., Pierre C., Sinninghe Damsté J.S. and Party N.S. (2007) Seafloor geological studies above active gas chimneys off Egypt (Central Nile Deep-sea Fan). Deep-Sea Research I 54, $1146-1172$.

Folmer O., Black M., Hoeh W., Lutz R. and Vrijenhoek R.C. (1994) DNA primers for amplification of mitochondrial cytochrome $c$ oxidase subunit I from diverse metazoan invertebrates. Molecular Marine Biology and Biotechnology 3, 294-299.

Fujiwara Y. (2003) Endosymbioses between invertebrates and chemosymbiotic bacteria. Japanese Journal of Benthology 58, 26-33.

Giribet G., Distel D.L., Polz M., Sterrer W. and Wheeler W.C. (2000) Triploblastic relationships with emphasis on the acoelomates and the position of Gnathostomulida, Cycliophora, Platyhelminthes and Chaetognata: a combined approach of $18 \mathrm{~S}$ rDNA sequences and morphology. Systematic Biology 49, 539-562.

Hoeh W.R., Black M.B., Gustafson R., Bogan A.E., Lutz R.A. and Vrijenhoek R.C. (1998) Testing alternative hypothesis of Neotrigonia (Bivalvia: Trigonioida) phylogenetic relationships using cytochrome $c$ oxidase subunit I DNA sequences. Malacologia $40(1-2), 267-278$.

Jones W.J., Won Y.J., Maas P.A.Y., Smith P.J., Lutz R.A. and Vrijenhoek R.C. (2006) Evolution of habitat use by deep-sea mussels. Marine Biology 148, 841-851.

Kamenev G.M. (2009) North Pacific species of the genus Solemya Lamarck, 1818 (Bivalvia: Solemyidae), with notes on Acharax johnsoni (Dall, 1891). Malacologia 51, 233-261.

Krueger D.M., Gallager S.M. and Cavanaugh C.M. (1992) Suspension feeding on phytoplankton by Solemya velum, a symbiont-containing clam. Marine Ecology Progress Series 86, 145-151.

Neulinger S.C., Sahling H., Suhling J. and Imhoff J.F. (2006) Presence of two phylogenetically distinct groups in the deep-sea mussel Acharax (Mollusca: Bivalvia: Solemyidae). Marine Ecology Progress Series 312, $161-168$.

Passmaneck Y.J., Schander C. and Halanych K.M. (2004) Investigation of molluscan phylogeny using large sub-unit and small sub-unit nuclear rRNA sequences. Molecular Phylogenetics and Evolution 32, $25-38$.

Reid R.G.B. (1998) Order Solemyoida. In Beesley P.L., Ross J.G.B. and Wells A. (eds) Mollusca: the Southern synthesis. Fauna of Australia, Volume 5, part A. Melbourne: CSIRO Publishing, pp. 2241-2247.

Sahling H., Rickert D., Lee R.W., Linke P. and Suess E. (2002) Macrofaunal community structure and sulfide flux gas hydrate deposits from the Cascadia convergent margin, NE Pacific. Marine Ecology Progress Series 231, 121-138.

Sibuet M. and Olu K. (1998) Biogeographic, biodiversity and fluid dependence of deep-sea cold-seep communities at active and passive margins. Deep-Sea Research Part II 45, 517-567.

Taviani M. (2010) The deep-sea chemoautotroph microbial world as experienced by the Mediterranean metazoans through time. In Reiner J., Quéric N.-V. and Arp G. (eds) Advances in stromatolite geobiology. Springer, pp. 257-274. [Lecture Notes in Earth Sciences 131.] 
Taviani M., Angeletti L. and Ceregato A. (2008) Past and present chemosynthetic bivalves (family Solemyidae) inhabiting deep-sea cold vent and reducing environments in the Neogene of the Mediterranean basin. $33 \mathrm{rd}$ International Geological Congress, Oslo, 6-10 August 2008. [Abstracts.]

Taylor J.D. and Glover E.A. (2010) Chemosymbiotic bivalves. In Kiel S. (ed.) The vent and seep biota. Topics in Geobiology 33, 107-135.

and

Taylor J.D., Williams S.T. and Glover E.A. (2007) Evolutionary relationships of the bivalve family Thyasiridae (Mollusca: Bivalvia), monophyly and superfamily status. Journal of the Marine Biological Association of the United Kingdom 87, 565-574.

\section{Correspondence should be addressed to:}

C.F. Rodrigues

Université Pierre-et-Marie-Curie

UMR 7138 (UPMC CNRS IRD MNHN)

Systématique Adaptation, Evolution

Paris, 75052, France

email: clfrodrigues@gmail.com 